\title{
Stochastic simulation of sheep breeding schemes for Iceland, with a focus on ewe trait improvement
}

\author{
Eyjólfur Ingvi BJarnason ${ }^{1}$, Leiv SigbJørn EIKJE ${ }^{2}$ ANd GunNar KLeMETSDaL ${ }^{3}$ \\ ${ }^{1}$ The Icelandic Agricultural Advisory Centre, Hvanneyrargata 3, IS-311 Borgarnes, Iceland. ${ }^{2}$ Norwegian Sheep and Goat, \\ P.O. Box 104, N-1431 Aas, Norway. ${ }^{3}$ Department of Animal and Aquacultural Sciences, Norwegian University of Life \\ Sciences, P.O. Box 5003, N-1432 As, Norway. \\ E-mail:eyjolfur@rml.is; se@nsg.no;gunnar.klemetsdal@nmbu.no
}

\begin{abstract}
A sheep population of about 120,000 ewes was simulated: 6 months old test rams were used by natural mating within flock, while $\geq 1.5$ year old elite rams were used across flocks by AI. For each of three selection indices with different breeding goal weights for carcass vs. maternal traits, alternatives were sought to maximise genetic gain in the aggregated genotype for a rate of inbreeding $\leq 0.8 \%$ per generation. Similar breeding programs resulted for $20 \%, 40 \%$ or $80 \%$ breeding goal weights to maternal traits: With $80 \%$, number of ewes mated to each test ram was reduced from 50 to 35 and the elite mating percentage increased from 30 to 50 , for an unchanged number of ewes mated to each elite ram (900). Although the schemes were robust to the indices, genetic gain/variance per trait was not. Genetic gain in maternal traits is achievable if these traits are sufficiently weighted.
\end{abstract}

Keywords: Aggregated genotype, complex breeding goal, genetic gain, genetic gain per trait, rate of inbreeding, variation in genetic gain.

\section{YFIRLIT}

Rcektunarskipulag sauðfjár á Íslandi með áherslu á mceðraeiginleika

Útbúið var tölvulíkan sem líkti eftir bústærðum og skipulagi íslenskrar sauðfjárræktar m.v. að heildarfjöldi sauðfjár væri 120.000 kindur. Í líkaninu voru lambhrútar notaðir á heimabúum en eldri hrútar með sæðingum á öllum búum. Unnið var með prjár kynbótaeinkunnir með mismunandi vægi á skrokkgæða og mæðraeiginleika. Líkanið miðaði að pví að hámarka erfðaframför við aukningu í skyldleikarækt undir 0,8\% í hverri kynslóð. Nánast sama niðurstaða fékkst pegar vægi mæðraeiginleika í samsettri einkunn var 20\%, 40\% eða 80\%. Við $80 \%$ vægi mæðraeiginleika er betra að nota lambhrúta á færri ær innan hvers bús (35 ær í stað 50) og sæða meira (50\% í stað 30\%) en hámark 900 sæðingar á hvern sæðishrút. Pó niðurstaða hverrar samsettrar einkunnar sé skýr var erfðaframför einstakra eiginleika pað ekki. Erfðaframför í mæðraeiginleikum er hægt að ná séu eiginleikar vegnir rétt saman í samsettri einkunn.

\section{INTRODUCTION}

Sheep production is important in Iceland. In 2015 , it contributed to $23 \%$ of the national meat consumption (Statistics Iceland 2019). The North European short-tailed Icelandic sheep is the only breed in the country (Dýrmundsson \& Niżnikowski 2010), counting 476,000 winterfed sheep in December 2016, in about 2,500 flocks (The Icelandic Regional 
Development Institute 2017). In 2018, 95\% of the winterfed sheep were listed in the Icelandic sheep recording (The Icelandic Agricultural Advisory Centre 2018), and about 30,000 ewes are inseminated annually, mainly with fresh semen (Dýrmundsson et al. 2007). Two artificial insemination (AI) stations are in seasonal operation, with the capacity of 50 elite rams in total. Sheep breeders inseminate their own ewes intravaginally. Because Iceland is divided into isolation zones (to prevent the spread of diseases), AI not only contributes to the spread of genetic improvement but might also be used to establish an efficient breeding scheme. Currently, BLUP (Best Linear Unbiased Prediction, e.g., Lynch \& Walsh 1998) breeding values are calculated for four traits (carcass conformation grade, carcass fatness grade, prolificacy and productivity of ewes), but they are not weighted together into one index. Economic weights of traits under selection have never been calculated.

To supply information as to future planning of sheep breeding in Iceland, the stochastic simulation approach of Eikje et al. (2011) was adopted, utilising information relevant for Iceland. Eikje et al. (2011) recommended a scheme for Norway with young test rams (6 months old) used in natural mating in ram circles and all elite rams ( $\geq 1.5$ year olds) used in AI across all flocks (called NMAI2 in that study). For one set of weighting of traits, a scheme was preferred that had $40-50$ ewes per test ram, 700 ewes per elite ram, and 30\% elite mating. The first objective of this study was to examine the sensitivity of the result to the weighting of the traits. The second objective was to study changes in genetic gain per trait, especially the ewe traits, from changing the weights. A third objective was to calculate the variance in gain per trait, to add information as to how ewe traits should be included in future breeding schemes for sheep. In the future one can expect a development towards larger sheep flocks, requiring "easy care" ewes. Thus, ewe traits will become steadily more important.

\section{MATERIALS AND METHODS}

Simulation

Following Eikje et al. (2011) a full-scale sheep population was stochastically simulated. Because the flock sizes are expected to increase in Iceland, the 252 largest flocks with $>200$ ewes for the years 1995 - 2010 were simulated (Appendix 1; Table A1), amounting to about 120,000 ewes. For each flock the size was determined by utilising the cumulative distribution function that can be derived from Table A1 in Appendix 1. The flock structure was kept the same throughout the replicates. In the base population, ewes and rams were assigned age distributions from the cumulative distribution functions calculated from Table A2 in Appendix 1. For all individuals, true breeding values were assigned for weaning weight (direct and maternal-genetic), carcass weight, carcass conformation and fatness grades, and number of lambs borne of the ewe at one, two and three years of age, respectively, utilising the genetic parameters in Table A3 in Appendix 1. The multivariate true breeding values were variance corrected for inbreeding and calculated conventionally, as described by Eikje et al. (2012). Individual inbreeding coefficients were calculated by use of the algorithm of Meuwissen \& Luo (1992). Each year, mature ewes were culled according to the cumulative probability of being culled per age class as given in Table A4 in Appendix 1. In addition, ewes were culled if they did not conceive after two oestrous cycles, but for those being only half a year old every second was nevertheless kept. With natural mating and $\mathrm{AI}$, conception rates of $96 \%$ and $67 \%$ were assumed, respectively (The Icelandic Agricultural Advisory Centre 2016). For the selection candidates, BLUP breeding values were calculated as described in Eikje et al. (2012), and selection was on a selection index $(S I)$ calculated as:

$$
S I=\sum_{i=1}^{n} E B V_{i} \frac{v_{i}}{\sigma_{A_{i}}}
$$

where $E B V_{i}$ is the predicted breeding value for trait $i, v_{i}$ is the corresponding breeding goal 
weight, and $\sigma_{A}$ is the additive genetic standard deviation. Ewe and ram lambs were both selected within flock, ranked by combining the SI of the sire and dam the preceding year and the lamb's weaning weight deviation from the flock average; for details, see Eikje et al. (2011). Older ewes and rams were solely selected on SI, within flock for ewes and across flocks for rams. Ewe lambs replacing older, culled ewes were always ranked inferior to the older ones. Surplus animals were slaughtered. Elite rams in AI were mated with the best elite ewes, at random, and the remaining ewes were mated at random to test rams. Inseminated ewes that did not conceive were mated to a test ram. If the calculated inbreeding coefficient $(F)$ of the progeny exceeded $3.1 \%$, the mating was not accepted. However, after 5 unsuccessful attempts to find a ram resulting in offspring with the desired $F$, the mating was accepted. Furthermore, for recruitment purposes, it was necessary to simulate phenotypes for number of lambs born, allocated by utilising the information for female fertility given in Table A5 in Appendix 1; for details, see Eikje et al. (2011). A random half of all lambs born were assigned to each sex, for which the fractions given in Table A6 in Appendix 1 were randomly assigned to survive until weaning.

\section{Simulated breeding schemes}

For the described scheme NMAI2, with halfyear old rams selected and used for natural mating within flock and 1.5 years and older elite rams selected and used across flocks by AI, the following alternatives were simulated for each of the three selection indices SII, SI2 and SI3:

a) elite mating percentages (EM\%): 30, 50 and 70

b) numbers of ewes mated to each test ram (nEweTest): 20, 35 and 50, and

c) numbers of ewes inseminated to each elite ram (nEweElite): 500, 700, 900, 1,100 and 1,300 .

The indices SI1, SI2 and SI3 were assigned $80 / 20,60 / 40$ and 20/80 breeding goal weights
Table 1. Breeding goal weights $\left(v_{i}\right)$ per trait $(i)$ in the three selection indices (SII,SI2 and $S I 3$, respectively).

\begin{tabular}{lccc}
\hline Trait $(\boldsymbol{i})$ & SI1 & SI2 & SI3 \\
\hline Weaning weight, individual $(\mathrm{kg})$ & 0.00 & 0.00 & 0.00 \\
Carcass weight $(\mathrm{kg})$ & 26.67 & 20.00 & 6.67 \\
Carcass conformation grade & 26.67 & 20.00 & 6.67 \\
Carcass fatness grade & 26.67 & 20.00 & 6.67 \\
Weaning weight, & 10.00 & 20.00 & 40.00 \\
maternal-genetic (kg) & 3.33 & 6.67 & 12.50 \\
Number of lambs born, 1 year & 3.33 & 6.67 & 15.00 \\
Number of lambs born, 2 years & 3.33 & 6.67 & 12.50 \\
Number of lambs born, 3 years & & &
\end{tabular}

to carcass vs. maternal traits, respectively, according to the $v_{i}$ values given in Table 1 .

\section{Replicates and statistics}

Each scheme was run for 20 years and replicated 10 times $(h)$. In each replicate, the annual genetic gain in trait $i$ was estimated as a linear regression coefficient of the true breeding value for year $\left(b_{i}\right)$ over the last 15 years of selection. Genetic gain in the aggregate genotype per year $(\Delta G)$ in replicate $h$ was calculated as:

$$
\Delta G_{h}=\sum_{i=1}^{n} b_{i} \frac{v_{i}}{\sigma_{A_{i}}}
$$

Across replicate genetic gains in the aggregated genotype $(\Delta G)$ were only comparable within each selection index, while changes in each trait were comparable across indices.

In addition, in year 20 of the simulation the average cumulative genetic gain per trait was calculated across replicates $\left(G_{20}\right)$. Acrossreplicate variation per trait was obtained and given as the relative standard deviation, which was the absolute value of the coefficient of variation $(|C V|)$.

To calculate the rate of inbreeding per generation in replicate $h$ the following formula was used:

$\Delta F_{h}=\left(\left(\sum_{t=13}^{20}\left(F_{t}-F_{t-1}\right) /\left(1-F_{t-1}\right)\right) / 8\right)\left(\left(L_{S S}+L_{S D}+L_{D S}+L_{D D}\right) / 4\right)$

where $F_{t}$ is the average inbreeding coefficient in year $t$, and $L_{S S}, L_{S D}, L_{D S}$ and $L_{D D}$ are corresponding calculated generation intervals 
of sire to son, sire to daughter, dam to son and dam to daughter, respectively. Alternatives were sought that resulted in the largest possible across-replicate $\Delta G$ for a corresponding $\Delta F \leq$ $0.8 \%$ per generation, as in Eikje et al. (2011).

\section{RESULTS AND DISCUSSION}

Two of the three selection indices simulated (SI1 and SI2) had the largest genetic gain in the aggregated genotype for nEweTest $=50$, $\mathrm{EM} \%=30$ and nEweElite $=900$, while SI3 had
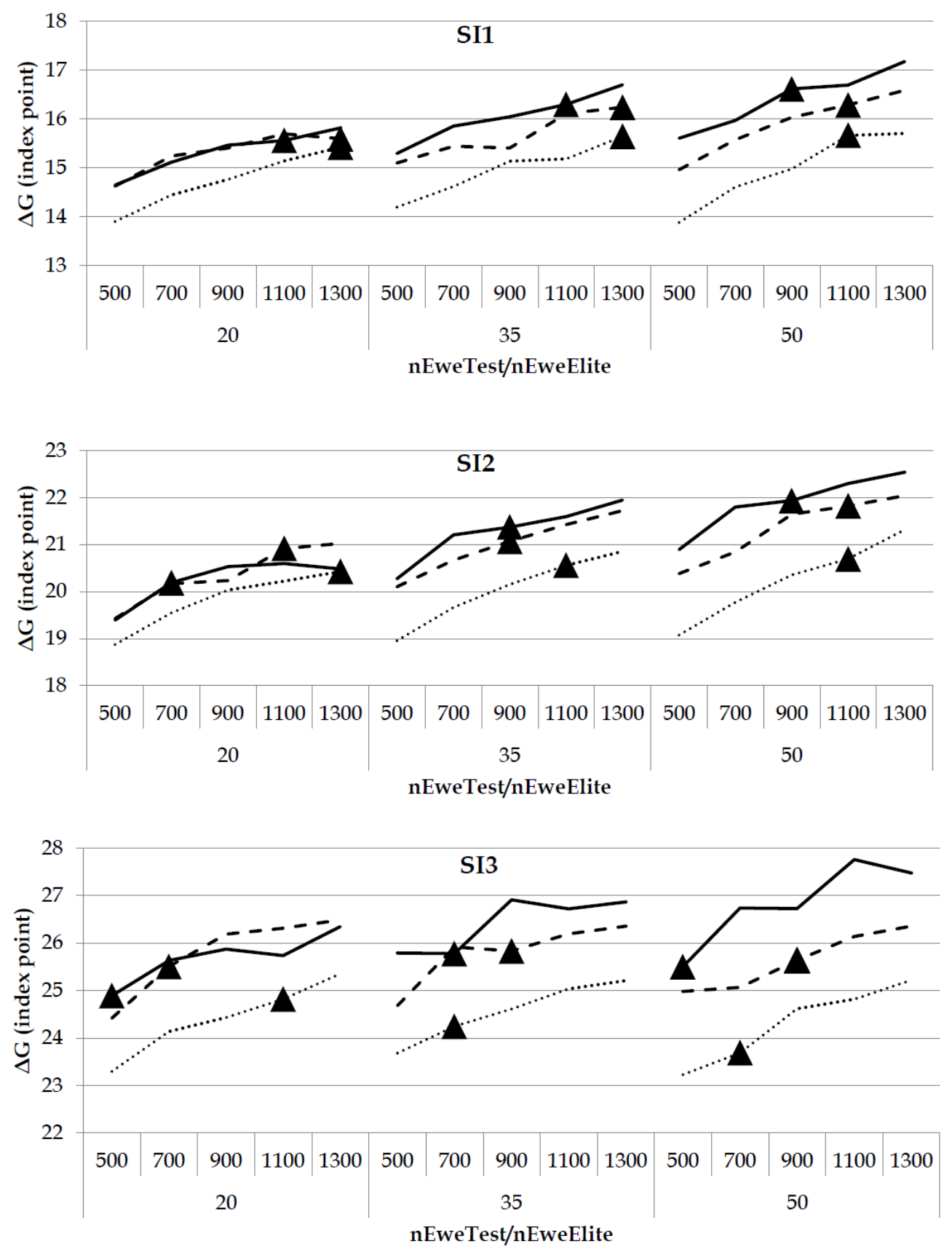

nEweTest/nEweElite

$$
\mathrm{EM} \%=30 \quad-\quad-\quad \mathrm{EM} \%=50 \quad \text {........ } \mathrm{EM} \%=70
$$

Figure 1. Across replicate annual genetic gain in aggregate genotype per year $(\Delta G)$ for varying EM\%, for increasing number of ewes inseminated with elite rams (nEweElite) within number of ewes mated to test rams (nEweTest), in three selection indices (SII, SI2 and SI3). The triangle shows the highest genetic gain for a constraint on the across replicate rate of inbreeding $\leq 0.8 \%$ per generation. 
the largest gain for $n E w e T e s t=35$, and $\mathrm{EM} \%$ $=50$ for the same nEweElite (Figure 1). The latter alternative means an enlarged number of both selected test and elite rams. Although the parameters were set for Iceland, the same results were obtained as those by Eikje et al. (2011), i.e. that the test rams should be intensively used (40-50 ewes each), the elite mating percentage should be medium (30\%), and number of ewes inseminated by each elite ram should be high (700).

Thus, the designs chosen for the three selection indices (SI1, SI2 and SI3, respectively) were similar. This demonstrates that the preferred breeding design chosen for an aggregated genotype for the given parameters is robust to changes in the breeding goal weights. In SI3, the rate of inbreeding was controlled from selecting more rams since pedigree information became more important with an increased EM\% which is expected to enhance co-selection of relatives and increase the inbreeding rate. However, note that with SI3 and nEweTest $=35$ an almost comparable result (Figure 1) was produced for $\mathrm{EM} \%=30$ and $\mathrm{nEweElite}=700$, i.e., that elite rams alternatively had to be used less to control co-selection and rate of inbreeding.
Despite roughly the same breeding program advised by use of either of the three selection indices, the predicted genetic gain in the various traits varied considerably between SII, SI2 and SI3, respectively (Figure 2). In SI1 with $80 / 20 \%$ breeding goal weights to carcass vs. maternal traits (in all three indices half the weight for maternal traits allocated to the maternal-genetic effect on weaning weight and the other half to number of lambs born) annual genetic response was the largest in carcass traits; 0.42 of one genetic standard deviation for carcass weight, less than 0.11 for maternal-genetic effect on weaning weight, and $0.05-0.08$ for number of lambs born. Applying weights of $60 / 40 \%$ (SI2; Figure 2) increased gain in maternal traits considerably relative to SII by 2.67 times for maternal-genetic effect on weaning weight and 1.59 times for the average over number of lambs born, respectively. In SI2, relative to SI1, some reduction in gain for carcass traits was obtained, or 0.84 times for carcass weight (Figure 2). A further change in breeding goal weights to $20 / 80 \%$ for carcass vs. maternal traits (SI3; Figure 2) resulted in an additional increase in gain for maternal-genetic effect on weaning weight and for number of lambs

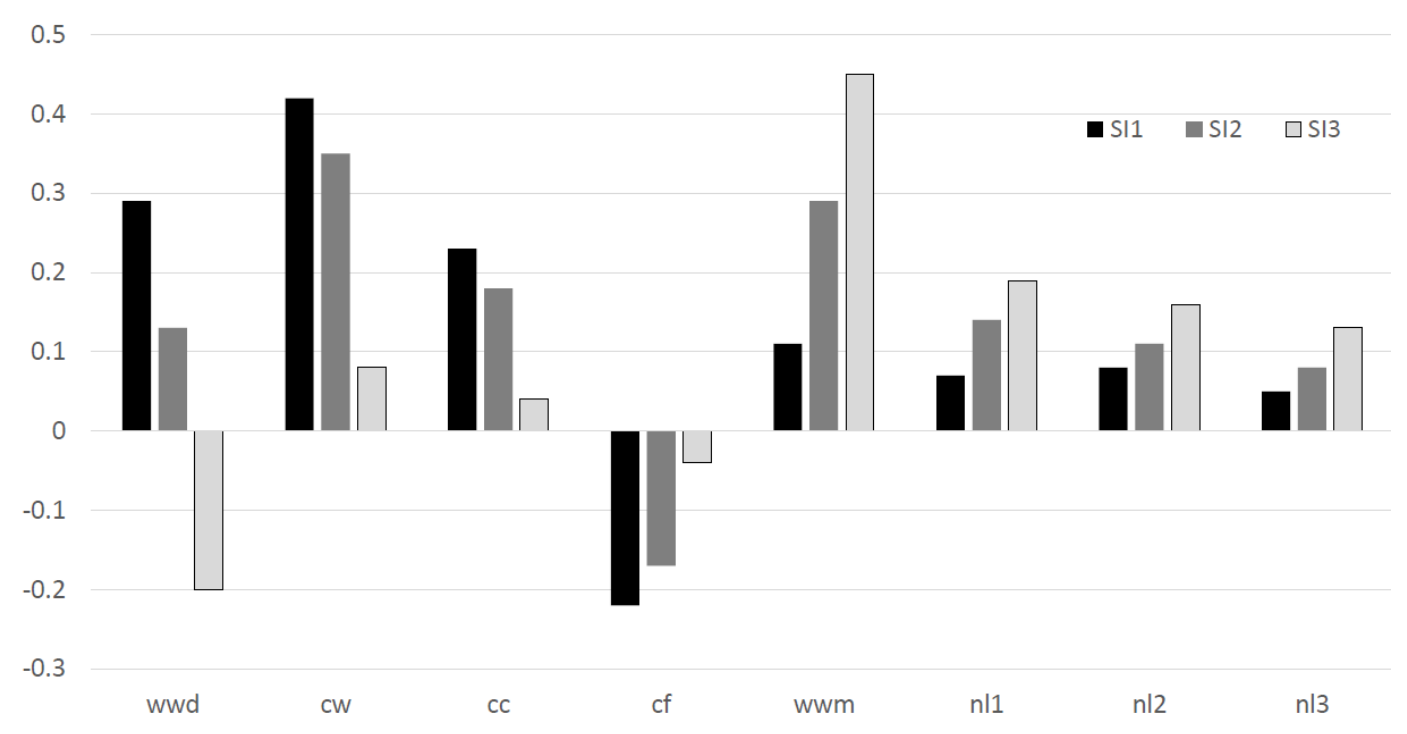

Figure 2. Across replicate annual genetic gain in additive genetic standard deviation units in trait $i$ (wwd $=$ weaning weight, individual $(\mathrm{kg}), \mathrm{cw}=$ carcass weight $(\mathrm{kg}), \mathrm{cc}=$ carcass conformation grade, $\mathrm{cf}=$ carcass fatness grade, wwm = weaning weight, maternal-genetic $(\mathrm{kg}), \mathrm{nl} 1, \mathrm{nl} 2$ and $\mathrm{nl} 3=$ number of lambs born at 1,2 and 3 years of age, respectively), for the scheme with the largest genetic gain in the aggregated genotype and with a rate of inbreeding $\leq 0.8 \%$ per generation, per selection index (SII, SI2 and SI3, respectively). 
born, to 0.45 and $>0.13$, respectively, of one genetic standard deviation. Moreover, with SI3 a negative genetic development was obtained in the direct effect on weaning weight because the direct and the maternal-genetic effect on weaning weight were assumed to have a negative genetic correlation (Appendix 1; Table A3). Consequently, almost no genetic gain was obtained in carcass traits. In all three indices, carcass conformation grade increased whereas carcass fatness grade was reduced (Figure 2). This was expected with positive $E B V \mathrm{~s}$ assigned for lean animals (reversing the scale) and both traits assumed genetically uncorrelated with the remaining traits. For both these traits, genetic change varied with the size of the breeding goal weights allocated, being the largest in SII (Figure 2).

In general, the results shown confirm Smith (1983) who found that the response is largest in traits with a large product for the economic weight and the accuracy of selection, i.e., carcass weight and maternal-genetic effect on weaning weight, depending on whether SII or SI3 apply (Table 1). Secondly, the results demonstrate that the simulated breeding scheme will produce gain in carcass traits, which is not unexpected, but can also produce gain in maternal traits if these are sufficiently weighted. This comes, however, at the expense of close to no genetic gain in carcass traits, and even with a genetic decline in the direct effect on weaning weight (Figure 2). Thus, when the genetic correlation between the direct and the maternal-genetic effect on weaning weight is as large as assumed here $(-0.55)$, assigning a huge weight to the maternal-genetic effect on weaning weight in fact has the potential to stop a genetic increase in the adult weight. However, the summed effect of the direct and the maternal-genetic effect on weaning weight was still slightly positive, or 0.06 of the summed genetic standard deviations.

The across-replicate cumulative genetic gain in year 20 and the relative standard deviation, i.e., the absolute value of the coefficient of variation, for the three SIs are given in Table 2. First, note that for number of lambs born, those traits being simulated independent of other traits (Appendix 1; Table A3) and for maternal-genetic effect on weaning weight the relative standard deviations were reduced considerably from $S I 1$ to $S I 3$, i.e., with increasing breeding goal weights to ewe traits. Secondly, in SI2 relative to SII the relative standard deviation was close to unchanged for carcass weight, but increased for carcass

Table 2. Across replicate cumulative genetic level in year $20\left(G_{20}\right)$ and absolute value of coefficient of variation (illustrating relative standard deviation) $\left(|C V|_{20}\right)$, in trait $i$, for the scheme with the largest genetic gain in the aggregated genotype and with a rate of inbreeding $\leq 0.8 \%$ per generation, per selection index $(S I 1, S I 2$ and $S I 3$, respectively).

\begin{tabular}{lccccccc}
\hline & \multicolumn{2}{c}{$\boldsymbol{S I 1}$} & \multicolumn{2}{c}{$\boldsymbol{S I 2}$} & \multicolumn{2}{c}{$\boldsymbol{S I 3}$} \\
\cline { 2 - 8 } Trait (i) & ${ }_{\boldsymbol{G} \mathbf{0}} \mathbf{0}$ & $|\boldsymbol{C}|_{20}$ & $\boldsymbol{G}_{20}$ & $|\boldsymbol{C} \boldsymbol{V}|_{20}$ & $\boldsymbol{G}_{20}$ & $|\boldsymbol{C} \boldsymbol{V}|_{20}$ \\
\hline Weaning weight, individual $(\mathrm{kg})$ & 9.52 & 0.07 & 4.69 & 0.07 & -4.87 & 0.11 \\
Carcass weight $(\mathrm{kg})$ & 6.65 & 0.03 & 5.55 & 0.03 & 1.47 & 0.14 \\
Carcass conformation grade & 2.96 & 0.06 & 2.36 & 0.11 & 0.57 & 0.18 \\
Carcass fatness grade & -2.54 & 0.06 & -2.00 & 0.11 & -0.46 & 0.36 \\
Weaning weight, maternal-genetic (kg) & 1.58 & 0.17 & 4.96 & 0.04 & 8.30 & 0.03 \\
Number of lambs born, 1 year & 0.20 & 0.36 & 0.39 & 0.11 & 0.58 & 0.05 \\
Number of lambs born, 2 years & 0.19 & 0.35 & 0.38 & 0.19 & 0.59 & 0.07 \\
Number of lambs born, 3 years & 0.17 & 0.23 & 0.30 & 0.19 & 0.48 & 0.07 \\
\hline
\end{tabular}


quality traits, i.e., most for the two traits lowest in accuracy of selection of the three. Carcass quality traits were assumed to be uncorrelated with weaning weight, while carcass weight was correlated (Appendix 1; Table A3) and weaning weight was observed for all animals. In addition, from SI2 to SI3 the relative standard deviation increased for all carcass traits, since the breeding goal weights for these traits were lowest in SI3. Finally, Table 2 again illustrates that moving from SII to SI2 a large genetic improvement was observed for the maternal traits for a small reduction in gain of carcass traits. In SI2, the more balanced gain across traits was followed by a substantially lowered maximum relative standard deviation, 0.19 in $S I 2$ vs. 0.36 in $S I 1$, i.e., for less risk. In SI3, risk again increased since breeding goal weights became more unevenly distributed across traits, amounting to 0.36 for carcass fatness grade. So, in general, the variation in outcome was largest for the least weighted traits.

With ewe traits becoming more important, an alternative to pure breeding would be to develop a sire line and a dam line that could be utilised through crossbreeding (Smith 1964). In theory, this can be relevant with a negative genetic correlation between weaning weight and maternal-genetic effect on weaning weight, as assumed here (Appendix 1; Table A3). An assumption for the result of Smith (1964) is the existence of a high reproductive rate. However, crossbreeding cannot be used for the ewes taking part in the breeding program in the dam line, relevant for NMAI2, counting 117,322 ewes (from Appendix 1; Table A1). Moreover, it cannot be used in the commercial herds for the fraction of the ewes needed to recruit the dam line. If ewes on average produce for 6 years (from Appendix 1; Table A4), giving birth to an average of 1.8 lambs (from Appendix 1; Table A5), of equal sex ratio, from which $50 \%$ of the females are recruited, the fraction recruited becomes $1 /(6 \mathrm{x}$ $1.8 \times 0.5 \times 0.5)=0.37$. This corresponds to a total of 132,843 ewes, assuming 476,000 ewes in Iceland and subtracting the 117,322 ewes in the breeding program. Thus, a total of 250,165 ewes cannot be allocated to crossbreeding, i.e., a fraction of 0.53 of the ewes. Consequently, the proportion of slaughter from the dam line ( $d$ in Appendix 2) becomes high, meaning that the breeding goal of the dam line approaches the breeding goal of the one line. This logic demonstrates that the obvious challenge to future sheep breeding is to develop schemes that are efficient in pure breeding with respect to ewe traits.

Eikje et al. (2011) have shown that the NMAI2 scheme outperformed a scheme denoted NMAI1, in which elite rams were used one year locally before being selected for AI at 2.5 years of age, as has been practised in Norway. With both schemes, one strategy to increase genetic gain in ewe traits could be to increase the generation interval to allow for a progeny test for these traits. This means to explore schemes in which sires are first selected on progeny test results at 2.5 years of age rather than at the assumed 1.5 years of age, as conventionally done in sheep breeding programs focusing on carcass traits (both NMAI1 and NMAI2). Lillehammer et al. (2020) have simulated such a progenytesting scheme with a progeny group size of test rams of ca. 50. Relative to the NMAI1 scheme practised in Norway, the progeny-testing scheme produced an improvement in maternal traits of about $20 \%$, for a similar reduction in carcass traits. One should expect the results in such a scheme to be heavily dependent on the progeny group size of test rams that needs to be optimised. Progeny testing and delayed selection till 2.5 years of age would also be relevant if other maternal traits were to be considered more important, e.g., mastitis, since such a trait can be assumed to be antagonistically related to the maternal-genetic effect on weaning weight and possibly carcass weight. This is in analogy with the undesirable genetic relationship that exists between production and health traits in dairy breeding (e.g., Heringstad et al. 1999).

On the other hand, since NMAI2 outperformed NMAI1 (Eikje et al. 2011), a further shortening of the generation interval could be advantageous in a conventional scheme. However, when either selecting AI 
sires at 0.5 or 1.5 years of age, the accuracy of selection for ewe traits is low, but might become improved through genotyping of all test rams, utilised through genomic selection. Lillehammer et al. (2020) have simulated both these strategies under genomic selection and obtained a considerable increase in gain of ewe traits relative to that in their NMAI1 scheme $(57 \%$ and $77 \%$, respectively), for some reduction in gain for carcass traits. However, rates of inbreeding also increased, especially when selecting 6 month old sires, leading to recommend selection of sires with genomic selection at 1.5 years of age. In genomic selection schemes, additional gain can be obtained from genotyping of ewes. However, the biggest challenge is to record precise phenotypes for the most important ewe traits.

\section{CONCLUSIONS}

A similar design of a breeding program was concluded based on the results of the three selection indices, with either $20 \%, 40 \%$ or $80 \%$ breeding goal weights to maternal traits, respectively, and with the remaining weights to carcass traits. However, with the $80 \%$ alternative nEweTest was reduced from 50 to 35 and $\mathrm{EM} \%$ increased from 30 to 50 for an unchanged nEweElite (900). Although the design of the preferred scheme was only slightly affected by the indices, the gain in the various traits was heavily influenced. Moreover, variation in genetic gain from replicate to replicate for a trait (i.e., risk) increased with a more uneven allocation of breeding goal weights to traits, with the largest risk for the least weighted traits. With the assumed genetic correlation structure between weaning weight, maternal-genetic effect on weaning weight and carcass weight, the maternal traits need sufficient weighting to become considerably changed by selection.

\section{ACKNOWLEDGEMENTS}

Dr Morten Svendsen is thanked for the derivations in Appendix 2. The research was financed by the memorial fund of Dr Halldor Palsson and the Agricultural Productivity Fund in Iceland.

\section{REFERENCES}

Árnason T \& Jónmundsson JV 2008. Multiple trait genetic evaluation of ewe traits in Icelandic sheep. Journal of Animal Breeding and Genetics 125, 390-396.

https://doi.org/10.1111/j.1439-0388.2008.00734.x.

Dýrmundsson ÓR \& Niżnikowski R 2010. North

European short-tailed breeds of sheep: a review. Animal 4, 1275-1282.

https://doi.org/10.1017/S175173110999156X.

Dýrmundsson ÓR, Jónmundsson JV \& Ólafsson

T 2007. The development of artificial insemination in sheep and goats in Iceland. Accessed 07.01.2013 at http://www.eaap.org/Previous_ Annual_Meetings/2007Dublin/Papers/S14_3_ Dyrmundsson.pdf.

Eikje LS, Schaeffer RL, Ådnøy T \& Klemetsdal G 2011. Sheep breeding schemes utilising artificial insemination; large-scale simulation with a complex breeding goal. Animal 5, 367-377.

https://doi.org/10.1017/S1751731110002053.

Eikje LS, Schaeffer LR, Ådnøy T, Klemetsdal G. \& Ødegård, J 2012. A method for the prediction of multitrait breeding values for use in stochastic simulation to compare progeny-testing schemes, with large progeny groups for proven sires. Journal of Animal Breeding and Genetics 129, 188-194.

https://doi.org/10.1111/j.1439-0388.2011.00952.x.

Einarsson E, Eythórsdóttir E, Smith CR \& Jónmundsson JV 2015. Genetic parameters for lamb carcass traits assessed by video image analysis, EUROP classification and in vivo measurements. Icelandic Agricultural Sciences 28, 3-14.

https://doi.org/10.16886/IAS.2015.01.

Heringstad B, Klemetsdal G \& Ruane J 1999. Clinical mastitis in Norwegian Cattle: Frequency, variance components and genetic correlation with protein yield. Journal of Dairy Science 82, 13251330.

https://doi.org/10.3168/jds.S0022-0302(99)75356-7.

Lillehammer M, Sonesson AK, Klemetsdal G, Blichfeldt $T$ \& Meuwissen THE 2020. Genomic selection strategies to improve maternal traits in Norwegian White sheep. Journal of Animal Breeding and Genetics. https://doi.org/10.1111/jbg.12475. 
Lynch M \& Walsh B 1998. Genetics and analysis of quantitative traits, $1^{\text {st }}$ ed. Sinauer Associates Inc., Sunderland, MA, $980 \mathrm{p}$.

Meuwissen THE \& Luo Z 1992. Computing inbreeding coefficients in large populations Genetics Selection Evolution 24, 305-313.

https://doi.org/10.1186/1297-9686-24-4-305.

Smith C 1964. The use of specialised sire and dam lines in selection for meat production. Animal Production 6, 337-364.

https://doi.org/10.1017/S0003356100022133.

Smith C 1983. Effects of changes in economic weights on the efficiency of index selection. Journal of Animal Science 56, 1057-1064.

https://doi.org/10.2527/jas1983.5651057x.

Statistics Iceland 2019. Annual meat consumption per capita from 1983. Accessed 16.01.2019 at http://px.hagstofa.is/pxen/sq/ce9c81e8-ff7e-4ffd8a04-907e7d838c22.

The Icelandic Agricultural Advisory Centre 2016. Niðurstöður skýrsluhalds 2016. [Results from sheep recording in 2016]. (In Icelandic) Accessed 16.01.2019 at https://www.rml.is/is/forrit-ogskyrsluhald/fjarvisis/fjarvisis-eldri-nidurstodur.

The Icelandic Agricultural Advisory Centre 2018. Niðurstöður skýrsluhalds 2018. [Results from sheep recording in 2018]. (In Icelandic) Accessed 21.06.2019 at https://www.rml.is/is/forrit-ogskyrsluhald/fjarvisis/nidurstodur-skyrsluhalds.

The Icelandic Regional Development Institute 2017. Dreifing sauðfjár á Íslandi. [Distribution of sheep farms in Iceland]. (In Icelandic) Accessed 16.01.2019 at https://www.byggdastofnun.is/static/ files/Byggdabrunnur/dreifing-saudfjar-2016-uppf. pdf.

Received 12.7.2019

Accepted 2.4.2020 